\title{
THERMAL-INDUCED POLYMERIZATION SHRINKAGE IN SILORANE VERSUS METHACRYLATE BASED RESIN COMPOSITE
}

\author{
CONTRAÇÃO DE POLIMERAÇÃO INDUZIDA TERMICAMENTEEM RESINAS \\ COMPOSTAS A BASE DE SILORANO E METACRILATO
}

\begin{abstract}
Wagner BASEGGIO ${ }^{1}$; Flavia Pardo Salata NAHSAN²; Luciana Fávaro FRANCISCONI-DOSRIOS $^{3}$; Marta Daniele Lima Menezes ALVES ${ }^{4}$; Eduardo Bastista FRANCO

1. Adjunct Professor, Paranaense University, Cascavel, PR, Brazil. wagnerbaseggio@ yahoo.com.br; 2. Adjunct Professor, Federal University of Sergipe, Aracaju, SE, Brazil; 3. Assistant Professor, DDS, PhD, Department of Operative Dentistry School of Dentistry, University of São Paulo, São Paulo, SP, Brazil; 4. Master Student in Dentistry, Program in Dentistry, Federal University of Sergipe, Aracaju, SE, Brazil; 5. Full Professor, Department of Operative Dentistry, Endodontics and Dental Materials. Bauru School of Dentistry, University of São Paulo, Bauru-SP, Brazil
\end{abstract}

\begin{abstract}
Shrinkage is a limitation of resin composite, compromising the clinical longevity of the restorative procedure. In an attempt to reduce their harmful effects, researchers have studied monomers with lower values of contraction. As a result, low-shrinkage composites were developed. This study evaluated quantitatively the shrinkage as a function of power density increase based on methacrylates, comparing them with silorane based resin, and qualitatively regarding gap formation between the adhesive interface as function of tooth substrate. Resin Filtek P90 and Filtek Z250 were polymerized with the device Blue Star 3 with 200, 400,600, 800 and $1000 \mathrm{~mW} / \mathrm{cm}^{2}$ keeping volume constant in 12 $\mathrm{mm}^{3}$. For qualitative analysis of restorative interface, class $\mathrm{V}$ cavity preparations in bovine incisors were restored in $\left(2 \times 2 \times 2 \mathrm{~mm}^{3}\right)$, photoactivated with the same values of irradiance, and analyzed by scanning electron microscopy at the interface of the wall surrounding enamel, dentin and axial. The quantitative results of the polymerization shrinkage were analyzed by two-way ANOVA and Tukey's test ( $\mathrm{p} \leq 0.05)$, while qualitative data were submitedd to Mann-Whitney's, Kruskal-Wallis' and Miller's tests. The progressive increase in power density directly influenced the polymerization shrinkage of the materials studied, although the silorane based resin demonstrated significantly lower values. The marginal integrity was influenced by the dental substrate and the power density used.
\end{abstract}

KEYWORDS: Power density. Shrinkage. Silorane based resin.

\section{INTRODUCTION}

The volumetric polymerization shrinkage still represents an important factor limiting the behavior and clinical longevity (CONSANI et al., 2016) of composite restorations.

The polymerization reaction of methacrylate-based resin composites can be characterized into two phases, according to the viscoelastic behavior of the material: pre- and postgel (SAKAGUCHI et al., 1997). In the pre-gel phase, the material has a low elastic modulus and is capable of undergoing a transient deformation through sliding of the forming polymer chains which dissipates the stress generated by volumetric shrinkage within the matrix itself, avoiding the development of significant stresses at the restorative-tooth interface (SAKAGUCHI et al.,1997; FEILZER et al., 1990; FEILZER et al., 1995). After gelation, as the elastic modulus increases, the molecular mobility decreases and the polymer undergoes a permanent deformation (DAVIDSON; FEILZER, 1997) generating stresses to the surrounding tooth structures. (FEILZER et al., 1995; DAVIDSON; FEILZER, 1997;
TANTBIROJN et al., 2011;MEIRA et al, 2011; PFEIFER et al. 2008; BOARO et al., 2010).

Slower polymerization reactions influence the leakage characteristics of the material and lengthen the pre-gel phase, resulting in longer periods during which the material is capable of dissipating the stresses generated before acquiring a high elastic modulus, consequently reducing the shrinkage stress values (PFEIFER et al., 2006).

The polymeric chains of BisGMA-based resin composites are gradually structured into a tridimensional network, resulting from the copolymerization among high molecular weight monomers such as bisphenol-A glycidyl methacrylate (BisGMA), urethane dimethacrylate (UDMA) and ethoxylated bisphenol-A glycidyl methacrylate (BisEMA), with diluents such as triethyleneglycol dimethacrylate (TEGDMA) (BOARO et al., 2010; RUEGGEBERG et al, 1994; FLOYD; DICKENS, 2006; BRAGA; FERRACANE,2004). The approximation of these molecules results in a volume reduction of the material which generates internal stresses that may or may not jeopardize the bonding interface, depending on the magnitude and moment during which they developed. If the magnitude of the 
stress generated is greater than the material's bond strength to tooth substrate, a marginal gap will be formed which potentializes the deleterious effects of marginal microleakage, consequently leading to the leakage of bacterias and oral fluids through the tooth/restoration interface (FERRACANE, 1994).

Once the polymerization shrinkage is a consequence of the breaking of the carbon double bonds followed by the approximation of the methacrylate-based monomers to form the polymer chains, researches have aimed at attempting to improve the organic matrix of dental composite resins by employing alternative monomers (SHARAFEDDIN et al., 2016; WEINMANN et al., 2005; BAGIS 2009). As a result, in 2007, a siloranebased composite became commercially available in the American dental market.

To date, the literature has corroborated that silorane-based composites have less than $1 \%$ of total volumetric shrinkage (WEINMANN et al., 2005; ILIE; HICKEL, 2006; BAGIS et al., 2009). Notwithstanding, both the shrinkage stress and its effects on the adaptation of the adhesive interface cannot be determined by the analysis of the polymerization shrinkage itself (BOARO et al, 2010; VAN ENDE et al, 2010).
Considering that high power densities may induce excessive polymerization shrinkage of methacrylate-based composites by compromising the bonding stability of the adhesive interface and that silorane-based composites requires high irradiances to be converted into heat for facilitating the polymerization reaction, the aim of this study was to compare quantitatively the polymerization shrinkage and qualitatively the restorative interface, as the increasing of the power densities emitted on methacrylate- and silorane-based composites. The null hypothesis was that results for the lowshrinkage composites are not different from regular composites.

\section{MATERIAL AND METHODS}

Onde hundred specimens (cavity and restorations) were made at $23 \pm 2{ }^{\circ} \mathrm{C}$ and $50+10 \%$ relative humidity by using two resin composites: FiltekTM Z-250 (3M ESPE) - methacrylate-baseand FiltekTM P90 (3M ESPE) -silane-based-, all in A-2 shade. The specimens were light cured for 40 seconds with a halogen curing light Blue Star (Microdont, São Paulo, Brazil) with several power densities $\left(\mathrm{mW} / \mathrm{cm}^{2}\right)$ (Table 1$)$.

Table 1. Distribution of the specimens regarding to the experimental condition for the quantitative analysis of the polymerization shrinkage.

\begin{tabular}{llcc}
\hline Group & Resin Composite & $\begin{array}{l}\text { Density } \\
(\mathbf{m W / c m 2})\end{array}$ & Time (s) \\
\hline G1 $(\mathrm{n}=10)$ & Filtek Z250 & 200 & 40 \\
G2 (n=10) & Filtek Z250 & 400 & 40 \\
G3 (n=10) & Filtek Z250 & 600 & 40 \\
G4 (n=10) & Filtek Z250 & 800 & 40 \\
G5 (n=10) & Filtek Z250 & 1000 & 40 \\
G6 (n=10) & Filtek P90 & 200 & 40 \\
G7 (n=10) & Filtek P90 & 400 & 40 \\
G8 (n=10) & Filtek P90 & 600 & 40 \\
G9 (n=10) & Filtek P90 & 800 & 40 \\
G10 (n=10) & Filtek P90 & 1000 & 40 \\
\hline
\end{tabular}

The sample distribution regarding the quantitative analysis of the shrinkage force and qualitative analysis of the adhesive interface is seen in Tables 1 and 2.

\section{Shrinkage force}

A universal testing machine (Emic DL 500, Emic Equipamentos e Sistemas de Ensaio Ltda, Paraná, Brazil) and two rectangular steel bases with 
$6.0 \mathrm{~mm}$ length and $2.0 \mathrm{~mm}$ width were used in the study.

The upper steel base was coupled to the mobile arm of the testing machine through a load cell of $10 \mathrm{~kg}$ and the lower steel base was coupled to the fixed arm of the testing machine through a BENCOR Multi-T device, with a distance of 1.0 $\mathrm{mm}$ between the bases. Therefore, the volume of the resin composite increment inserted between the two bases was constantly of $12.0 \mathrm{~mm}^{3}$, that is, the base or increment length multiplied by the thickness and by the height: volume $=6.0 \times 2.0 \times 1.0$ or $\mathrm{V}=12.0$ $\mathrm{mm}^{3}$ (Figure1).

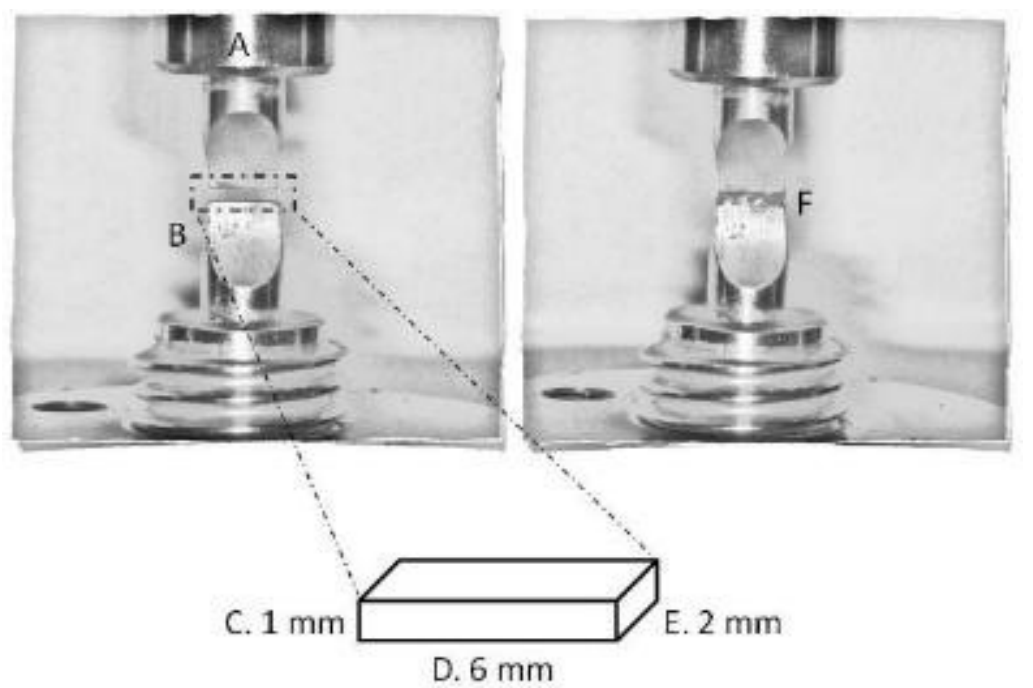

Figure 1. Equipament used in the test. A.10 kilos load cell; B. Metallic base fixed to the machine; C. $1 \mathrm{~mm}$ space to composite resin insertion; D.Metallic base length; E.Base metallic width and F.Composite resin increment placed to be tested.

Following the adaptation and ascertainment of the distances between the steel bases, this space was filled with a single increment of resin composite. A light-curing unit (Blue Star 3, Microdont Produtos e Equipamentos Odontológicos, São Paulo, Brazil) was then placed by centering its tip between the steel bases, allowing the light irradiation on the entire sample. Because the lightcuring device had a power density fixed at $1550 \mathrm{~mW} / \mathrm{cm}^{2}$, cylindrical plastic devices with different lengths and same diameters were customized and coupled to the tip of the light-curing unit, aiming to modify and modulate the emitted power density that would reach the restorative material at $200 \mathrm{~mW} / \mathrm{cm}^{2}, 400 \mathrm{~mW} / \mathrm{cm}^{2}, 600$ $\mathrm{mW} / \mathrm{cm}^{2}, 800 \mathrm{~mW} / \mathrm{cm}^{2}$ ad $1000 \mathrm{~mW} / \mathrm{cm}^{2}$. The power density was checked through a radiometer (Curing Radiometer / Model 100 P/N 10503/Demetron Research Corp - Demetron) prior to the light-curing of each sample. Ten tests were executed for each group. The test began at the same moment of the light-curing and the total test time was set at 120 seconds. The graphic records of the force (Newton) and time (seconds) (s) were recorded by the specific software of the universal testing machine.

The relationship between the distance of the light-curing device's tip and the power density emitted onto the material were, as follows: $38 \mathrm{~mm}$ $\left(200 \mathrm{~mW} / \mathrm{cm}^{2}\right), 28 \mathrm{~mm}\left(400 \mathrm{~mW} / \mathrm{cm}^{2}\right), 19 \mathrm{~mm}(600$ $\left.\mathrm{mW} / \mathrm{cm}^{2}\right), 13 \mathrm{~mm}\left(800 \mathrm{~mW} / \mathrm{cm}^{2}\right)$ and $9 \mathrm{~mm}(1000$ $\mathrm{mW} / \mathrm{cm}^{2}$ ).

\section{Analysis of the restorative interface}

The qualitative analysis, on the other hand, comprised a randomized selection of bovine teeth (lower central incisors), where class $\mathrm{V}$ cavity preparations were prepared and finished (2 mm deep X $2 \mathrm{~mm}$ diameter). The preparations were restored according to the manufacturers' instructions with either a methacrylate-based composite or a siloranebased one and submitted to light-curing according to the different power densities. The bonding interface between the restorative material/cavity preparation walls was evaluated at three different sites: surrounding cavity walls - external enamel wall, external dentin wall and internal axial wall (Table 2). 
Table 2. Distribution of the specimen in different experimental conditions for the qualitative analysis of the restorative material/cavity preparation walls bonding interface.

\begin{tabular}{|c|c|c|c|}
\hline \multirow[t]{8}{*}{$\begin{array}{l}\text { Resin } \\
\text { composite }\end{array}$} & $\begin{array}{c}\text { Power density } \\
\left(\mathrm{mW} / \mathrm{cm}^{2}\right)\end{array}$ & Cavity wall & Group \\
\hline & \multirow{3}{*}{200} & surrounding enamel & G1e \\
\hline & & surrounding dentin & G1d \\
\hline & & Axial & G1a \\
\hline & \multirow{3}{*}{400} & surrounding enamel & G2e \\
\hline & & surrounding dentin & G2d \\
\hline & & Axial & G2a \\
\hline & \multirow{3}{*}{600} & surrounding enamel & G3e \\
\hline \multirow[t]{15}{*}{ Filtek Z250 } & & surrounding dentin & G3d \\
\hline & & Axial & G3a \\
\hline & \multirow{3}{*}{800} & surrounding enamel & G4e \\
\hline & & surrounding dentin & G4d \\
\hline & & Axial & G4a \\
\hline & \multirow{3}{*}{1000} & surrounding enamel & G5e \\
\hline & & surrounding dentin & G5d \\
\hline & & Axial & G5a \\
\hline & \multirow{3}{*}{200} & surrounding enamel & G6e \\
\hline & & surrounding dentin & G6d \\
\hline & & Axial & G6a \\
\hline & \multirow{3}{*}{400} & surrounding enamel & G7e \\
\hline & & surrounding dentin & G7d \\
\hline & & Axial & G7a \\
\hline & \multirow{3}{*}{600} & surrounding enamel & G8e \\
\hline \multirow[t]{8}{*}{ Filtek P90 } & & surrounding dentin & G8d \\
\hline & & Axial & G8a \\
\hline & \multirow{3}{*}{800} & surrounding enamel & G9e \\
\hline & & surrounding dentin & G9d \\
\hline & & Axial & G9a \\
\hline & \multirow{3}{*}{1000} & surrounding enamel & G10e \\
\hline & & surrounding dentin & G10d \\
\hline & & Axial & G10a \\
\hline
\end{tabular}

After the execution of the restorations, the samples were immersed into deionized water for 24 hours, in an incubator at $37^{\circ} \mathrm{C}$, longitudinally sectioned in a cutting machine (Model 650-SBT/ South Bay Technology, San Diego, California) to separate the mesial and distal surfaces, cleaned with running water and coated (Sputter Coater - SCD050 (BalTec, Liechtenstein, Germany) for analysis in Scanning Electronic Microscopy (Zeiss-DSM 940 ${ }^{\mathrm{A}}$, Germany-Digital Scanning Microscope).

A total of 300 photomicrographs were obtained, that is, 10 photomicrographs for each cavity wall $(\mathrm{n}=3 \times 10=30)$, for each density power $(\mathrm{n}=5 \times 30=150)$, for each composite type $(\mathrm{n}=2 \times$ $150=300)$.

Each photograph had its enamel, dentin and axial surface measured and equally divided into thirds. The photographs were randomly distributed in a photographic book and sent to 3 different examiners, which did not know to which group each photo was assigned. These examiners were previously trained and calibrated according to the following criteria: 0 - gap absence in all interface; 1 - gap presence with extension of up to $1 / 3$ of the total margin; 2 - gap presence with extension between $1 / 3$ and $2 / 3$ of the total margin; 3 - gap 
presence with extension between $2 / 3$ and $3 / 3$ of the total margin. Each examiner scored the photos at two different moments, with a 15-day interval between the assessments, to measure inter- and intraexaminer agreement and consequently the calibration among the examiners (Figure 2).
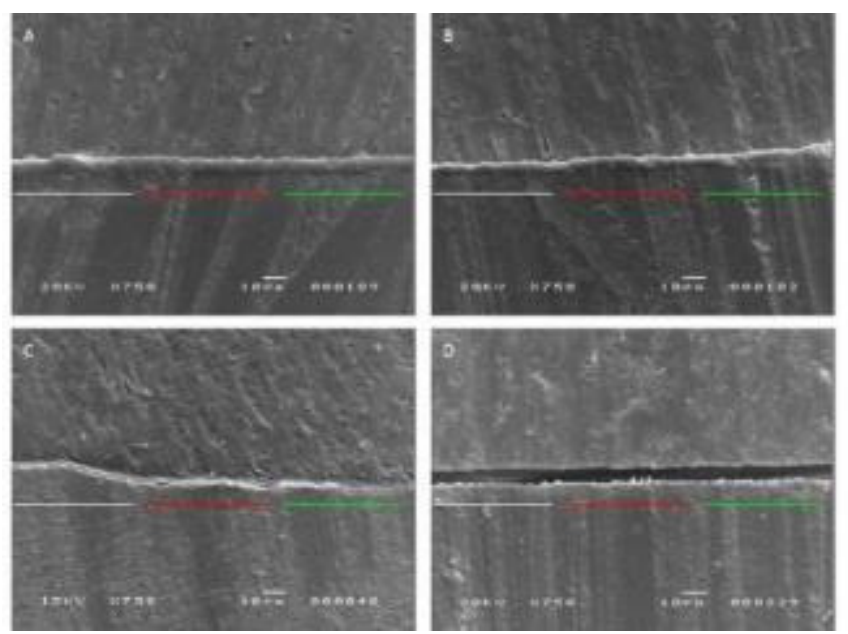

Figure 2. Division of the restorative axial interface extension representing the scores A. 0, B. 1, C. 2 e D. 3.

For the statistical analysis of the shrinkage force, two-way ANOVA and Tukey tests were used, with level of significance set at $5 \%,(\mathrm{p} \leq 0.05)$. The analysis of the restorative interface gap scores were performed by (1) Mann-Whitney test, for the comparison among the power densities, (2) KruskalWallis test, for the comparison among the power densities and the inter- and intragroup interfaces and (3) Miller test, for individual intergroup comparison. The statistical intra- and inter-examiner agreement was evaluated by Kappa Agreement method.

\section{RESULTS}

\section{Quantitative analysis of the polymerization shrinkage}

The characteristics of the cavity preparation used in the qualitative analysis of the restorative interface and the means of the shrinkage values of the groups tested and are seen in Table 3 and 4; Figures 3 and 4).

Table 3. Mean (M), standard deviation (SD), coefficient of variation (CV) and characteristics of the cavity preparation used in the qualitative analysis of the restorative interface.

\begin{tabular}{lccccc}
\hline & Diameter $(\mathbf{m m})$ & Depth(mm) & $\begin{array}{c}\text { Enamel } \\
\text { thickness }(\mathbf{m m})\end{array}$ & $\begin{array}{c}\text { Dentin thickness } \\
(\mathbf{m m})\end{array}$ & Volume $\left(\mathbf{m m}^{\mathbf{3}}\right)$ \\
\hline M & 2 & 2 & 0,7 & 1,3 & 6,28 \\
DP & 0,0 & 0,0 & 0,1 & 0,2 & 0,0 \\
\hline CV & $\mathbf{0 \%}$ & $\mathbf{0 \%}$ & $\mathbf{2 , 3 \%}$ & $\mathbf{8 , 8 \%}$ & $\mathbf{0 \%}$ \\
\hline
\end{tabular}

Table 4. Mean, standard deviation, and statistical significance of the polymerization shrinkage of the different groups tested.

\begin{tabular}{|c|c|c|c|}
\hline Groups & $\begin{array}{l}\text { Resin } \\
\text { composite }\end{array}$ & $\begin{array}{ll}\begin{array}{l}\text { Power } \\
\left(\mathrm{mW} / \mathrm{cm}^{2}\right)\end{array} & \text { dentisty }\end{array}$ & $\begin{array}{l}\text { Shrinkage (MPa) } \pm \\
\text { sd* }\end{array}$ \\
\hline G1 & \multirow{3}{*}{ Filtek $^{\mathrm{TM}} \mathrm{Z} 250$} & 200 & $0.93 \mathrm{~A} \pm 0.073$ \\
\hline G2 & & 400 & $1.29 \mathrm{~B} \pm 0.104$ \\
\hline G3 & & 600 & $1.65 \mathrm{C} \pm 0.103$ \\
\hline
\end{tabular}




\begin{tabular}{|c|c|c|c|}
\hline G4 & & 800 & $1.95 \mathrm{D} \pm 0.081$ \\
\hline G5 & & 1000 & $2.36 \mathrm{E} \pm 0.101$ \\
\hline G6 & \multirow{5}{*}{ Filtek $^{\mathrm{TM}} \mathrm{P} 90$} & 200 & $0.08 \mathrm{~F} \pm 0.022$ \\
\hline G7 & & 400 & $0.21 \mathrm{G} \pm 0.027$ \\
\hline G8 & & 600 & $0.37 \mathrm{H} \pm 0.043$ \\
\hline G9 & & 800 & $0.53 \mathrm{I} \pm 0.049$ \\
\hline G10 & & 1000 & $0.65 \mathrm{~J} \pm 0.046$ \\
\hline
\end{tabular}
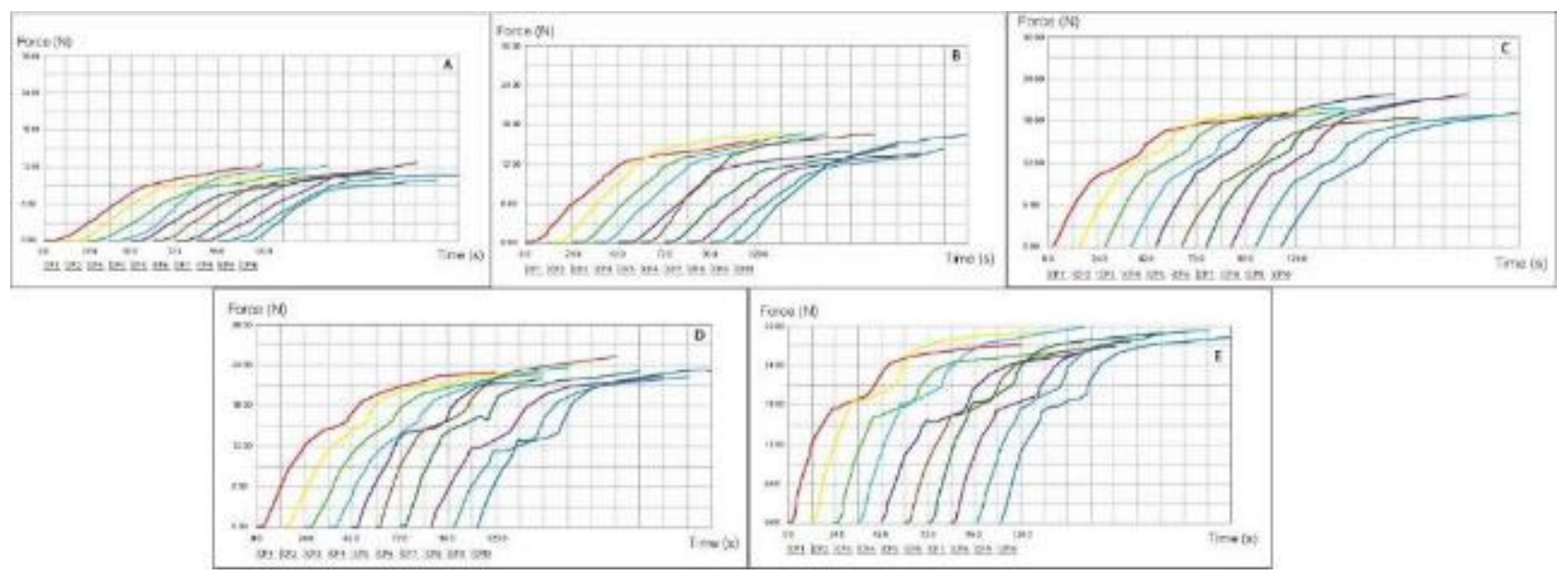

Figure 3. Graph of the mean shrinkage $(\mathrm{N})$ values generated during the polymerization of Filtek Z250 composite with the following power densities (A) $200 \mathrm{~mW} / \mathrm{cm}^{2}$; (B) $400 \mathrm{~mW} / \mathrm{cm}^{2}$; (C) $600 \mathrm{~mW} / \mathrm{cm}^{2}$; (D) $800 \mathrm{~mW} / \mathrm{cm}^{2}$ and (E) $1000 \mathrm{~mW} / \mathrm{cm}^{2}$.

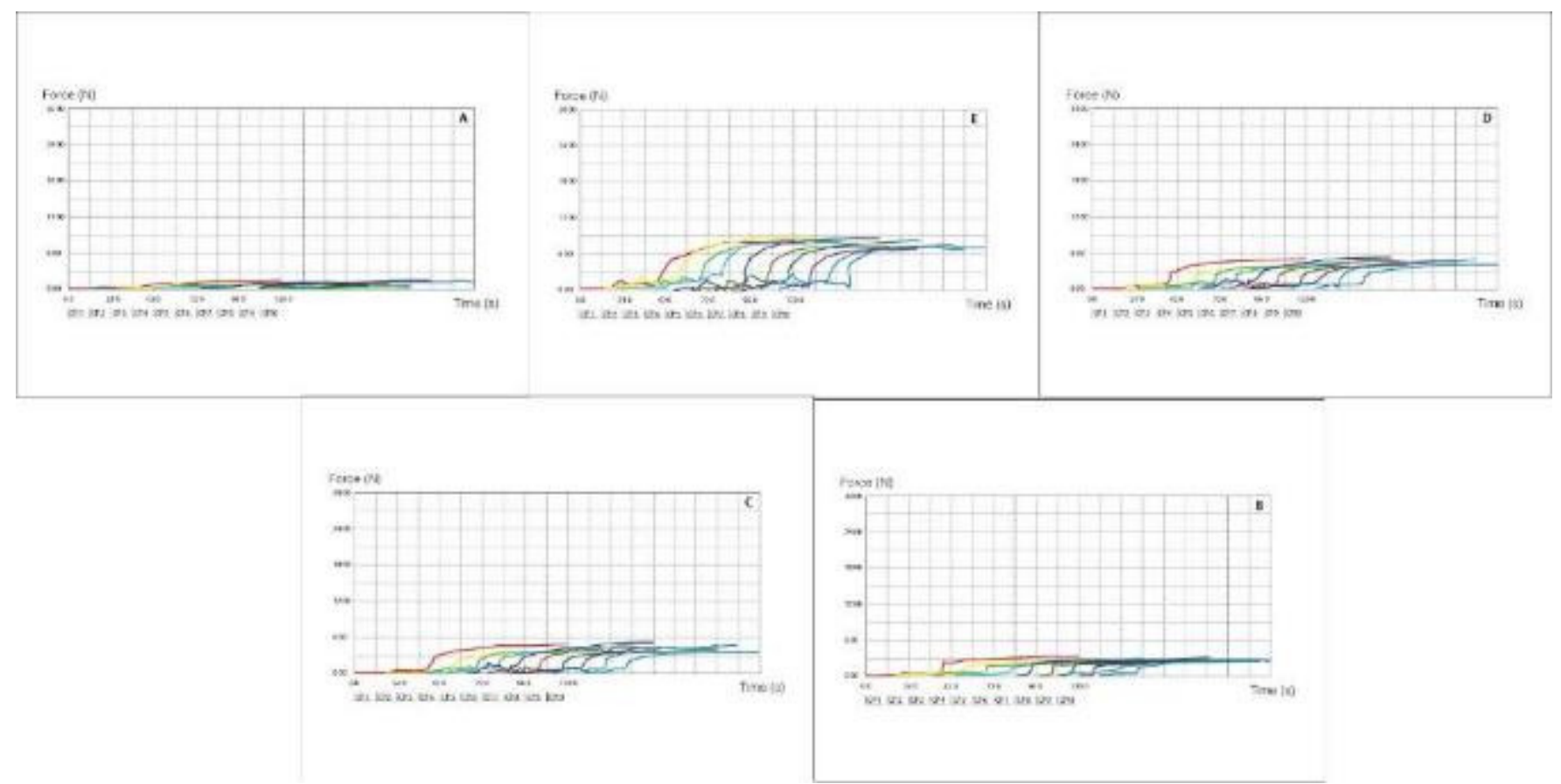

Figure 4. Graph of the mean shrinkage (N) )values generated during the polymerization of Filtek P90 composite with the following power densities (A) $200 \mathrm{~mW} / \mathrm{cm}^{2}$; (B) $400 \mathrm{~mW} / \mathrm{cm}^{2}$; (C) $600 \mathrm{~mW} / \mathrm{cm}^{2}$; (D) $800 \mathrm{~mW} / \mathrm{cm}^{2}$ and (E) $1000 \mathrm{~mW} / \mathrm{cm}^{2}$. 


\section{Qualitative analysis of the restorative interface}

By evaluating Filtek Z250 composite, regardless of the power density employed, the enamel margin did not undergo marginal gap. For dentinal margins, power density equal to or greater than $200 \mathrm{~mW} / \mathrm{cm}^{2}$ induced the gap formation, predominating the score $3 \quad 96 \%$ of the photomigraphs evaluated). However, on the axial wall, the gap in the restorative interface occurred with power density values higher than $600 \mathrm{~mW} / \mathrm{cm}^{2}$; integrity of the axial wall was seen with power densities of $200 \mathrm{~mW} / \mathrm{cm}^{2}$ and $400 \mathrm{~mW} / \mathrm{cm}^{2}$ (Figures 5 to 10$)$..

On the other hand, Filtek P90 composite assessment showed that the enamel marginal gap occurred at a power density equal to or greater than $600 \mathrm{~mW} / \mathrm{cm}^{2}$. In dentinal margins, the restorative interface was preserved only at a power density of $200 \mathrm{~mW} / \mathrm{cm}^{2}$. For values of $400 \mathrm{~mW} / \mathrm{cm}^{2}, 68 \%$ of the photomicrographs were scored as 2 and $32 \%$ as 3 . However, by applying values equal to or greater than $600 \mathrm{~mW} / \mathrm{cm}^{2}, 100 \%$ of the photomicrographs were scored as 3 for marginal gap formation. In the axial wall, at power densities of $200 \mathrm{~mW} / \mathrm{cm}^{2}$ and $400 \mathrm{~mW} / \mathrm{cm}^{2}$, the adhesive interface was preserved and scored as 0 in $100 \%$ of the cases. At power density of $600 \mathrm{~mW} / \mathrm{cm}^{2}, \quad 71 \%$ of the photomicrographs were scored as 2 and $29 \%$ as 3 . At power density of $800 \mathrm{~mW} / \mathrm{cm}^{2}, 66 \%$ were scored as 2 and $34 \%$ as 3 . At power density of $1000 \mathrm{~mW} / \mathrm{cm}^{2}, 93 \%$ of the photomicrographs were scored as 3 while $7 \%$ were scored as 2 .

The percentage of inter-examiner agreement for the analysis of the enamel surrounding wall was $96 \%$ between the examiners 1 and 2,100\% between the examiners 1 and 3 and $96 \%$ between the examiners 2 and 3 . For the dentinal surrounding wall, the inter-examiner agreement values were $94 \%, 94 \%$ and $100 \%$, respectively. And for the axial surrounding wall, the inter-examiner agreement values were $90 \%, 84 \%$ and $84 \%$, respectively.

Kappa intra-examiner agreement, after the 15-day interval, was of $88 \%, 86 \%$ and $84 \%$ for the examiners 1,2 and 3 , respectively

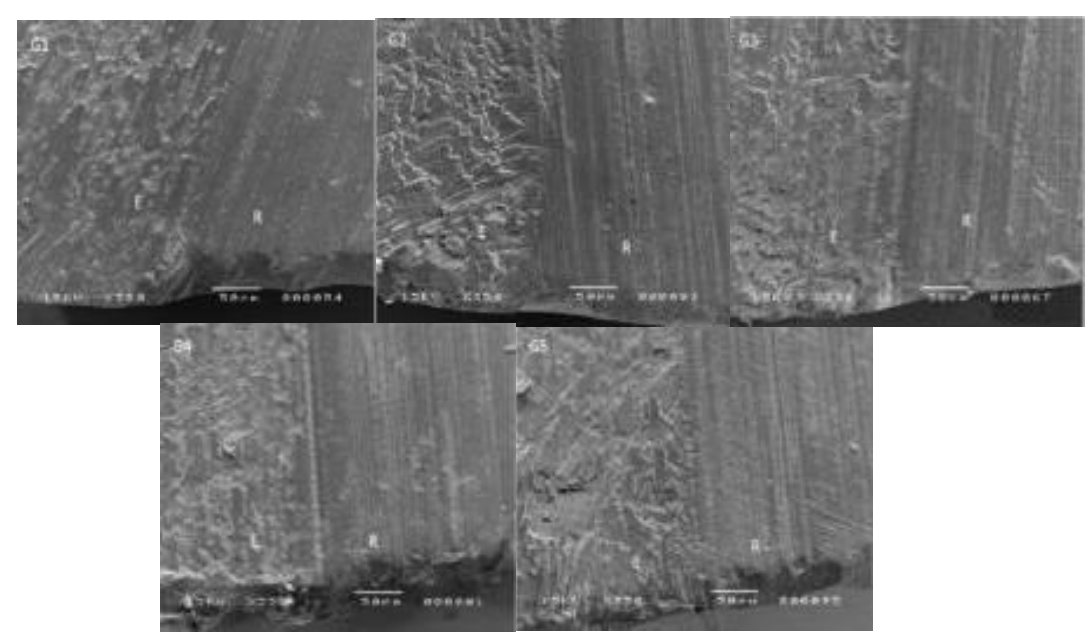

Figure 5. Photomicrographs of the enamel surrounding marginal gap for the groups restored with Filtek Z250 composite at different power densities. Scanning electron microscopy of the enamel marginal gap with the following power densities: G1. $200 \mathrm{~mW} / \mathrm{cm}^{2}$. G2. $400 \mathrm{~mW} / \mathrm{cm}^{2}$. G3. $600 \mathrm{~mW} / \mathrm{cm}^{2}$. G4. $800 \mathrm{~mW} / \mathrm{cm}^{2}$ and $\mathrm{G} 5.1000 \mathrm{~mW} / \mathrm{cm}^{2}$. (E) enamel and (R) resin composite. 


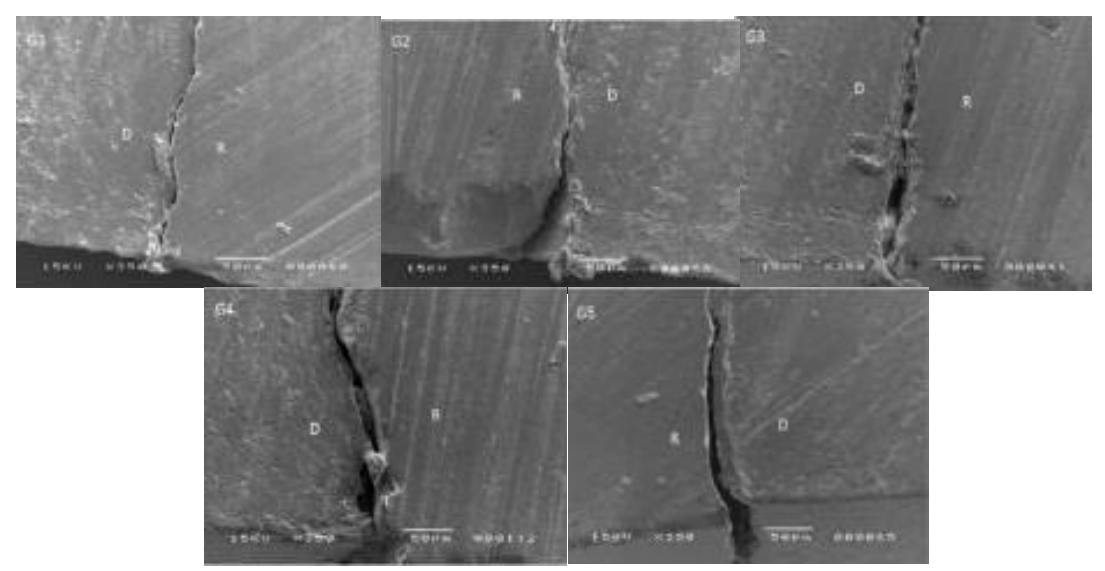

Figure 6. Photomicrographs of the dentin surrounding marginal gap for the groups restored with Filtek Z250 composite at different power densities. Scanning electron microscopy of the dentin marginal gap with the following power densities: G1. $200 \mathrm{~mW} / \mathrm{cm}^{2}$. G2. $400 \mathrm{~mW} / \mathrm{cm}^{2}$. G3. $600 \mathrm{~mW} / \mathrm{cm}^{2}$. G4. $800 \mathrm{~mW} / \mathrm{cm}^{2}$ and $\mathrm{G} 5.1000 \mathrm{~mW} / \mathrm{cm}^{2}$. (D) dentin and $(\mathrm{R})$ resin composite

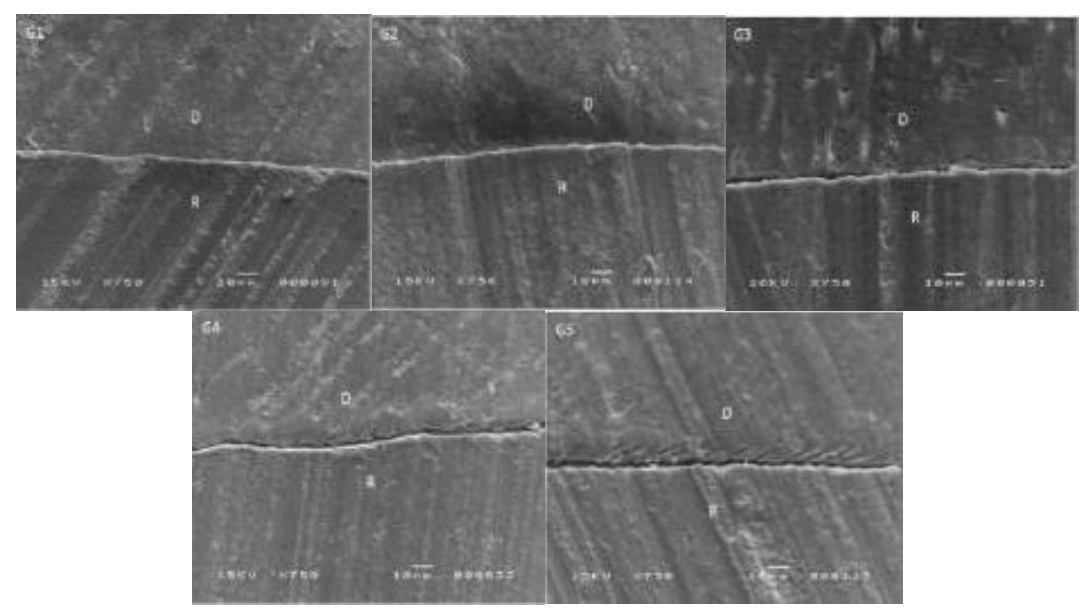

Figure 7. Photomicrographs of the dentin marginal gap (axial) for the groups restored with Filtek Z250 composite at different power densities. Scanning electron microscopy of the dentin marginal gap with the following power densities: G1. $200 \mathrm{~mW} / \mathrm{cm}^{2}$. G2. $400 \mathrm{~mW} / \mathrm{cm}^{2}$. G3. $600 \mathrm{~mW} / \mathrm{cm}^{2}$. G4. $800 \mathrm{~mW} / \mathrm{cm}^{2}$ and $\mathrm{G} 5.1000 \mathrm{~mW} / \mathrm{cm}^{2}$. (D) dentin and (R) resin composite.

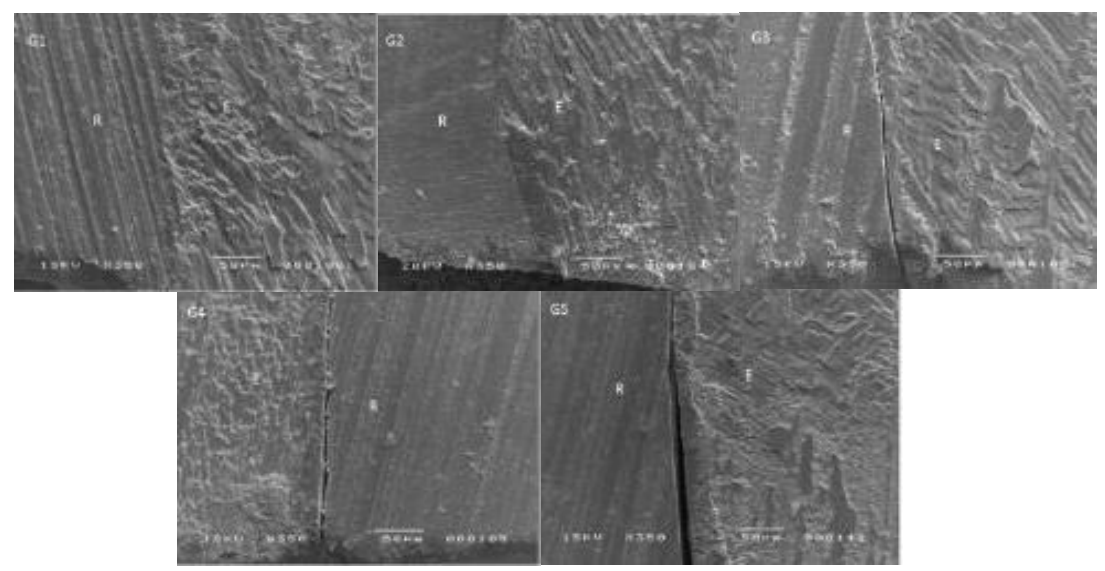

Figure 8. Photomicrographs of the enamel surrounding marginal gap for the groups restored with Filtek P90 composite at different power densities. Scanning electron microscopy of the enamel marginal gap with the following power densities: G1. $200 \mathrm{~mW} / \mathrm{cm}^{2}$. G2. $400 \mathrm{~mW} / \mathrm{cm}^{2}$. G3. $600 \mathrm{~mW} / \mathrm{cm}^{2}$. G4. $800 \mathrm{~mW} / \mathrm{cm}^{2}$ and $\mathrm{G} 5.1000 \mathrm{~mW} / \mathrm{cm}^{2}$. (E) enamel and $(\mathrm{R})$ resin composite. 


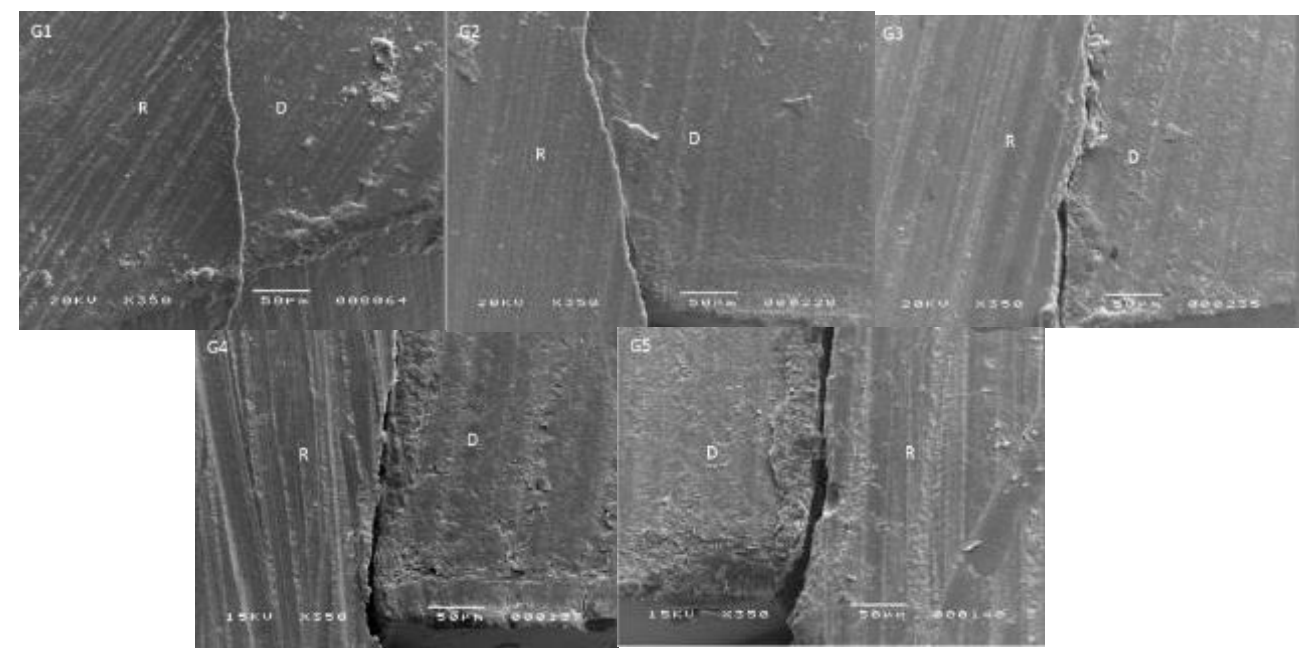

Figure 9. Photomicrographs of the dentin surrounding marginal gap for the groups restored with Filtek P90 composite at different power densities. Scanning electron microscopy of the dentin marginal gap with the following power densities: G1. $200 \mathrm{~mW} / \mathrm{cm}^{2}$. G2. $400 \mathrm{~mW} / \mathrm{cm}^{2}$. G3. $600 \mathrm{~mW} / \mathrm{cm}^{2}$. G4. $800 \mathrm{~mW} / \mathrm{cm}^{2}$ and $\mathrm{G} 5.1000 \mathrm{~mW} / \mathrm{cm}^{2}$. (D) dentin and (R) resin composite

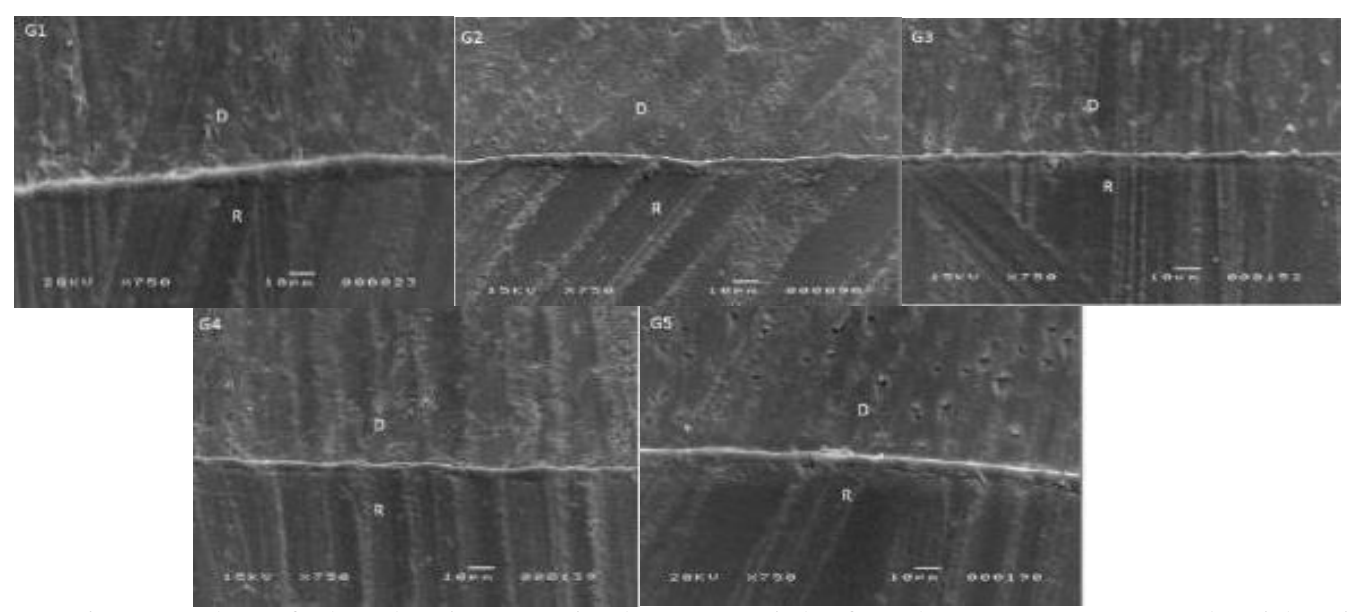

Figure 10. Photomicrographs of the dentin marginal gap (axial) for the groups restored with Filtek P90 composite at different power densities. Scanning electron microscopy of the dentin marginal gap with the following power densities: G1. $200 \mathrm{~mW} / \mathrm{cm} 2$. G2. $400 \mathrm{~mW} / \mathrm{cm} 2$. G3. $600 \mathrm{~mW} / \mathrm{cm} 2$. G4. $800 \mathrm{~mW} / \mathrm{cm} 2$ and $\mathrm{G} 5.1000 \mathrm{~mW} / \mathrm{cm} 2$. (D) dentin and (R) resin composite.

\section{DISCUSSION}

Silorane-based composites showed the least total polymerization shrinkage force values at the different power densities studied. The shrinkage development also occurs unevenly, expressed by the graph [force (N) X time (s)] seen in Figure 4 as a greater tendency towards horizontalization and formation of a plateau of the curves during lightcuring, with reduced initial values of shrinkage force followed by an abrupt verticalization of the shrinkage curve at the end of the light irradiation, developed directly proportional to the power density employed.
This different behavior of the silorane-based composite is due to the process of cationic polymerization reaction, completely different from the polymerization reaction of the methacrylatebased composites which occur through the breaking of carbon double bonds. Cationic polymerization requires three components: (1) an electron donor agent (negative electric charge), characterized by the photo-initiator (camphorquinone), (2) a cation (positive electric charge ion), represented by iodonium salt and (3) a heterocyclic monomer oxirane - a cyclic organic compound containing in its ring one or more different atoms from carbon, mainly oxygen, nitrogen or sulfur (ILIE; HICKEL, 2006; ODIAN, 2004; MATYJASZEWSKI; 
MATYJASZEWSKI, 1996; WEINMANN et al., 2005). A second electron donor agent (ethyl dimethylaminobenzoate) also helps the reaction. The proportion between the camphorquinone, the iodonium salt, and the electron donor agent is 2.1:0.85:0.05 ${ }^{27}$. The oxirane is an extremely small cyclic molecule (ODIAN, 2004). The smaller the monomer ring size is, the better its reactive characteristics are, favoring the polymer conversion (ODIAN, 2004; MATYJASZEWSKI; MATYJASZEWSKI, 1996). Four oxirane molecules are linked to one siloxane molecule to form a hybrid silorane monomer. The siloxane molecule was selected in the material composition due to its marked hydrophobic nature (WEINMANN et al., 2005). On the other hand, the oxirane molecule gives high reactivity and reduced shrinkage polymerization. During the initiation process, the light energy is irradiated to the material at a specific wavelength to sensitize the camphorquinone. This compound reaches an electronic excitation state and reacts by donating electrons and decompounding the iodonium salt cation, cleaving the oxirane cyclic ring. Additionally to this aforementioned reaction, camphorquinone reacts with a second electron donor agent, i.e., ethyl dimethylaminobenzoate. Next, after the decomposition of the iodonium salt, it becomes an active specie and initiates the propagation process, by reacting with the other, also active, monomer species through the opening of the oxirane cyclic rings, resulting in polymers. By opening the oxirane rings, the volumetric dimension of the monomer does not theoretically alter. Following, the termination process of the reaction initiates either when there is a lack of active oxirane monomers (ILIE; HICKEL, 2006; ODIAN, 2004; MATYJASZEWSKI; MATYJASZEWSKI, 1996; WEINMANN et al., 2005). The heat plays a main role in this reaction, favoring the acceleration of the oxirane rings opening (ILIE; HICKEL, 2006; ODIAN, 2004; MATYJASZEWSKI; MATYJASZEWSKI, 1996; WEINMANN et al., 2005).

These differences in the polymerization reaction of the silorane-based composite may justify the large plateau characteristic of low shrinkage values seen in the graph of Figure 4, during the 40 seconds of light-curing, regardless of the power density employed. Equally, the polymerization kinetics seems to be influenced by the mechanism of cationic polymerization, favoring a greater elongation of the pre-gel phase of the material, while the opening of the oxirane rings does not imply in reduction of the material volume (WEINMANN et al., 2005).

However, after the 40 seconds of light irradiance, it is evidenced an abrupt increase of the polymerization shrinkage of Filtek P90 composite, directly proportional to the power density employed. A possible explanation for that would be the continuous polymerization, even after the lightcuring, in association with the increase of the elastic modulus of the material and post-gel shrinkage (BOARO et al, 2010; EL-SAHN et al., 2011).

Additionally, it should be considered the possible influence of the temperature emitted by the light-curing device at the different power densities employed, that is, the thermal effect during lightcuring (ILIE; HICKEL, 2006; ILIE et al., 2007). In the end of the irradiation, there is an abrupt decrease of the temperature with consequent thermal shrinkage due to the cooling of the material. This generates an abrupt increase of the shrinkage values because of the addition of the shrinkage resulted from the increase of the elastic modulus when reaching the gel point, as expressed in the curves of the graph of the Figure 4 (ILIE; HICKEL, 2006; ILIE et al., 2007).

Concerning the shrinkage effect on the marginal adaptation of the materials to the cavity preparation walls, Filtek Z250 composite, generating shrinkage values $\left(1000 \mathrm{~mW} / \mathrm{cm}^{2}-2.36\right.$ $\mathrm{MPa}$ ), presented integrity of adaptation to the enamel surrounding wall. Unlikely, Filtek P90 composite showed an enamel gap for the densities of 600,800 and $1000 \mathrm{~mW} / \mathrm{cm}^{2}$, generating low shrinkage values $\left(600 \mathrm{~mW} / \mathrm{cm}^{2}-0.37 ; 800 \mathrm{~mW} / \mathrm{cm}^{2}\right.$ $\left.-0.53 ; 1000 \mathrm{~mW} / \mathrm{cm}^{2}-0.65 \mathrm{MPa}\right)$.

A possible hypothesis for these findings would be the highest bond strength values provided by the etch and rinse adhesive system used together with Filtek Z250 composite, due to the demineralization potential of $37 \%$ phosphoric acid (VAN MEERBEEK et al., 2011). The use of the self-etching adhesive system of Filtek P90 composite, similarly to those applied with methacrylate-based composites, may not have demineralized the enamel properly, resulting in a smaller infiltration capacity of the monomers and inducing marginal gaps (VAN MEERBEEK et al., 2011). A possible operative solution for this problem could be the etching of the enamel prior to the use of the adhesive system of Filtek P90 composite, although its manufacturer considers this as optional step.

It must be emphasized that at the minimum power density recommended by the manufacturer $\left(500 \mathrm{~mW} / \mathrm{cm}^{2}\right)$, all groups exhibited marginal gaps, 
at greater or smaller degree. However, although the power densities of 200 and $400 \mathrm{~mW} / \mathrm{cm}^{2}$ did not induce enamel gaps for Filtek P90 composite, the use of low irradiance values for this material is of great concern, especially considering the possible negative influence on the degree of conversion and mechanical properties, characterizing a not very well polymerized composite, similarly to the findings observed by Van Ende, Munck, Mine, Lambrechts e Meerbeek, (2010); Ilie, Hickel, (2006).

By assessing the marginal integrity of the dentinal surrounding wall for Filtek Z250 composite, the poor adaptation of the restorative interface for all the irradiances employed, as well as the linear relationship between the increase of the power density and the magnitude of poor adaptation, both in length and extension, may be seen in the photomicrographs of Figure 6. Accordingly, for the axial wall, the preservation of the marginal integrity only at the power densities of 200 and $400 \mathrm{~mW} / \mathrm{cm}^{2}$, may be observed in the photomicrographs of Figure 7. According to the aforementioned description, the polymerization kinetics of these materials plays a decisive role in marginal integrity, especially with the decrease of the pre-gel phase and increase of the polymerization shrinkage occurring due to higher light irradiations. Moreover, Versluis, Tantbirojn, Douglas (1998), demonstrated that the shrinkage vectors of methacrylate-based composites are influenced by some factors such as, composite adhesion to the substrate, number of walls adhered, and conversion degree of the material, that is, when the light is irradiated onto the target surface at a $90^{\circ}$ angle and directed to the surfaces (or previously adhered surfaces) while the material presents low elastic modulus; or directed to the material center when the elastic modulus increase, which favors the poor marginal adaptation.

It must be emphasized that methacrylatebased composites demands the presence of enamel in the cave-surface angle of the preparation to assure the preservation of the marginal integrity. Notwithstanding, this feature is not often present. Attempting to reduce the deleterious effects of polymerization shrinkage on dentin, the following strategies must be evaluated by the clinicians: lightcuring protocols to modulate the irradiance, by inducing the initial polymerization at low power densities, therefore elongating the pre-gel phase and providing longer time for the material to reach the elastic modulus and flow; use of glass ionomer cement cavity liners; adoption of the incremental insertion technique of composite resin; and cavity configuration (C factor) (SOH et al., 2004).
Despite of the induction of low shrinkage values, it could be observed the gap formation on the dentinal surrounding walls at the power densities of $400,600,800$ and $1000 \mathrm{~mW} / \mathrm{cm}^{2}$ for Filtek P90 composite, according to the photomicrographs of Figure 8.

Other factor that could be related to poor marginal adaptation is the great concentration of HEMA existing in the primer agent of the selfetching adhesive system used together with Filtek P90 composite. The hydrophilic features of HEMA, as well as other ions, determine a high osmotic concentration gradient (or hypertonicity) and induce the movement of water from the dentin towards the hybrid layer interface, resulting in water accumulation and blisters which can jeopardize the adhesion between the hydrophilic primer agent and the hydrophobic bonding agent, as reported by the findings of Mineet al., 2010. This would explain the breaking of the adhesive interface even with low shrinkage values.

This behavior has already been reported by TAY et al (2003a,2003b), for the methacrylatebased adhesive systems. These authors demonstrated the fluids permeation through the hydrophilic sites of the material and the presence of thin canals tracked by silver nitrate and so-called "water-trees", resulting from the passage of water during the permeability phenomena, morphologically evidencing the hybrid layer degradation.

Another possible explanation would be related to the handling and sculptability features of the silorane-based composites, exhibiting high viscosity and resulting in poor wettability on the substrate, as found by previous studies reporting problems related to the adaptation of this material because of its high rigidity and consequently presence of poor marginal adaptation and blisters within the restorations (YAMAZAKI et al., 2006).

By analyzing the marginal integrity of the axial walls for Filtek P90 composite groups irradiated at $200 \mathrm{~mW} / \mathrm{cm}^{2}$ and $400 \mathrm{~mW} / \mathrm{cm}^{2}$, comparatively to the groups irradiated at $600 \mathrm{~mW} / \mathrm{cm}^{2}$ and $800 \mathrm{~mW} / \mathrm{cm}^{2}$, a tendency towards similarity can be observed, although Miller's test evidenced significant statistical differences among groups. However, when the power density of 1000 $\mathrm{mW} / \mathrm{cm}^{2}$ was used, the visual and statistical differences of the marginal integrity were more evident. Such observations have been reported in the literature and accounted for the possible temperature decrease in the deepest layers, influenced by the light dispersion along the material (ILIE;HICKEL, 2006; ILIE et al, 2007). Once the temperature favors 
the increase of the molecular mobility and the reactivity of the opening of the oxirane ring, a smaller degree of conversion would be expected in these areas, and consequently, a smaller polymerization shrinkage (ILIE;HICKEL, 2006; ILIE et al, 2007). In addition to this factor, a smaller sensitization of camphorquinone by the increase of the distance of light irradiation would contribute for this phenomenon (HANSEN,; ASMUSSEN, 1997), which corroborates the results exhibited in Figure 10 , resulting in better adaptations on the axial wall at power densities of 200 and $400 \mathrm{~mW} / \mathrm{cm}^{2}$.

Nevertheless, the best integrity of the axial wall itself does not reflect in higher clinical longevity of the restoration, because it must be associated with the marginal integrity of the dentinal surrounding wall and adequate degree of conversion. Once these walls are closer to the light source, a higher thermal induction and photosensitization of camphorquinone reached by the power densities of 600,800 and $1000 \mathrm{~mW} / \mathrm{cm}^{2}$ implied in higher shrinkage and marginal gap, as observed in the images of Figures 9.

\section{CONCLUSIONS}

The power density increase create higher forces for both composite resins, despite of silorane based composite resins has shows lower values of shrinkage.

The marginal adaptation in he enamel surface is not injured as in the dentin, when power density is higher. Moreover, a lower shrinkage contraction presented by silorane based composite resins is not the only an isolated factor related to the tension magnitud and the vicoelastic behavior of the materials and solution the tooth adhesion problems.

RESUMO: Este estudo avaliou quantitativamente a contração de polimerização em função do aumento dos valores de densidade de potência irradiados em compósitos à base de metacrilatos e silorano, e qualitativamente a interface restauradora em relação à abertura de fendas marginais, em função da variação do tipo de substrato dentário. As resinas Filtek Z250 e Filtek P90 foram fotoativadas com 200, 400, 600, 800 e $1000 \mathrm{~mW} / \mathrm{cm}^{2}$, em um volume constante de $12 \mathrm{~mm}{ }^{3}$, e os valores de contração foram aferidos por meio da máquina de ensaios universal. Para análise qualitativa da interface restauradora, preparos cavitários classe $\mathrm{V}$ de $\left(2 \times 2 \times 2 \mathrm{~mm}^{3}\right)$ foram restaurados em incisivos bovinos, fotoativados com os mesmos valores de irradiância, e analisados em microscopia eletrônica de varredura nas interfaces da parede circundante em esmalte, parede circundante em dentina e parede axial. Os resultados quantitativos da contração de polimerização foram analisados pelo teste ANOVA a dois critérios e Tukey $(\mathrm{p} \leq 0,05)$ enquanto para os dados qualitativos os testes MannWhitney, Kruskal-Wallis e Miller foram empregados. O aumento progressivo da densidade de potência influenciou diretamente na contração de polimerização dos materiais estudados, não obstante a resina composta à base de silorano ter demonstrado valores significativamente menores. A integridade marginal sofreu influência do substrato dentário bem como da densidade de potência utilizada, para as duas resinas estudadas.

PALAVRAS-CHAVE: Densidade de potência, contração, resina composta a base de silorano.

\section{REFERENCES}

BACCHI, A. et al. Shrinkage, stress, and modulus of dimethacrylate, ormocer, and silorane composites. J Conserv Dent. Tamilnadu, v. 18, n. 5, p. 384-388, Sep-Oct, 2015.

BAGIS,Y. H.; BALTACIOGLU, I. H.; KAHYAOGULLARI, S. Comparing microleakage and the layering methods of silorane-based resin composite in wide class II MOD cavities. Oper Dent. Indianapolis, v. 34, p. 578-85.2009.

BOARO, L. C; GONÇALVES, F.; GUIMARÃES, T. C.; FERRACANE, J. L.; VERSLUIS, A.; BRAGA, R. R. Polymerization stress, shrinkage and elastic modulus of current low-shrinkage restorative composites. Dent Mater. Manchester, v. 26, n. 12, p. 1144-50, Dec.2010. https://doi.org/10.1016/j.dental.2010.08.003

BRAGA, R. R; FERRACANE, J. L. Alternatives in polymerization contraction stress management. J Appl Oral Sci. Bauru, v. 12, p. 1-11. 2004. 
CHEN, Y. C.; FERRACANE J. L.; PRAHL, S. A. Quantum yield of conversion of the photoinitiator camphorquinone. Dent Mater. Manchester, v. 23, n. 6, p. 655-64, Jun.2007.

https://doi.org/10.1016/j.dental.2006.06.005

CONSANI, R. L; MARINHO, T.; BACCHI, A.; CALDAS, R. A.; FEITOSA, V. P.; PFEIFER, C. S. Repair Strength in Simulated Restorations of Methacrylate- or Silorane-Based Composite Resins. Braz Dent J. Ribeirão Preto,v. 27, n. 4, p. 463-467, 2016.

DAVIDSON, C. L; FEILZER, A. J. Polymerization shrinkage and polymerization shrinkage stress in polymerbased restoratives. J Dent. Manchester, v. 25, n. 6, p. 435-40, Nov.1997.

EL-SAHN, N. A.; EL-KASSAS, D. W.; EL-DAMANHOURY, H. M.; FAHMY, O. M.; GOMAA, H.; PLATT, J. A. Effect of C-factor on microtensile bond strengths of low-shrinkage composites. Oper Dent. Indianapolis, v. 36, n. 3, p. 281-92, May-Jun. 2011. https://doi.org/10.2341/10-105-L

FEILZER, A. J; DE GEE, A. J; DAVIDSON, C. L. Relaxation of polymerization contraction shear stress by hygroscopic expansion. J Dent Res. Michigan, v. 69, n. 1, p. 36-9, Jan. 1990.

FEILZER, A. J; DOOREN, L. H.; DE GEE, A. J.; DAVIDSON, C. L. Influence of light intensity on polymerization shrinkage and integrity of restoration-cavity interface. Eur J Oral Sci. Malden, v. 103, n. 5, p. 322-6, Oct. 1995.

FERRACANE, J. L. Elution of leachable components from composites. J Oral Rehabil. Malden, v. 21, n. 4, p. 441-52, Jul.1994.

FLOYD, C. J, DICKENS, S. H. Network structure of Bis-GMA- and UDMA-based resin systems. Dent Mater. Manchester, v. 22, n. 12, p. 1143-9, Dec. 2006. https://doi.org/10.1016/j.dental.2005.10.009

HANSEN, E. K.; ASMUSSEN, E. Visible-light curing units: correlation between depth of cure and distace between exit window and resin surface. Acta Odontol Scand. Island, v. 55, n. 3, p. 162-6, Jun.1997. https://doi.org/10.3109/00016359709115410

ILIE, N.; HICKEL, R. Silorane-based dental composite: behavior and abilities. Dent Mater J. Tokyo, v. 25, n. 3, p. 445-54, Sep. 2006. https://doi.org/10.4012/dmj.25.445

ILIE, N.; JELEN, E.; CLEMENTINO-LUEDEMANN, T.; HICKEL, R. Low-shrinkage composite for dental application. Dent Mater J. Tokyo, v. 26, n. 2, p. 149-55, Mar. 2007. https://doi.org/10.4012/dmj.26.149

MATYJASZEWSKI, K.; MATYJASZEWSKI, M. Cationic polymerization: mechanisms, synthesis and applications. London: CRC Press,1996. p. 1-784.

MEIRA, J. B;, BRAGA, R. R; BALLESTER, R. Y; TANAKA, C. B.; VERSLUIS, A. Understanding contradictory data in contraction stress tests. J Dent Res. Michigan, v. 90, n. 3, p. 365-70, Mar. 2011.

MINE, A.; DE MUNCK, J.; VAN ENDE, A, CARDOSO, M. V, KUBOKI, T., YOSHIDA, Y., VAN MEERBEEK, B. TEM characterization of a silorane composite bonded to enamel/dentin. Dent Mater. Manchester, v. 26, n. 6, p. 524-32, Jun. 2010. https://doi.org/10.1016/j.dental.2010.01.010

ODIAN, G. Principles of polymerization. (4 ed). New York: Wiley-Interscience, 2004. p. 15-832. https://doi.org/10.1002/047147875X

PALIN, W. M.; FLEMING, G. J.; NATHWANI, H.; BURKE; F. J.; RANDALL, R. C. In vitro cuspal deflection and microleakage of maxillary premolars restored with novel low-shrink dental composites. Dent Mater. Manchester, v. 21, n. 4, p. 324-35, Apr. 2005. https://doi.org/10.1016/j.dental.2004.05.005 
PEUTZFELDT, A. Resin composites in dentistry: the monomer systems. Eur J Oral Sci., Malden. v. 105, n. 2, p. 97-116, Apr. 1997.

PFEIFER, C. S.; BRAGA, R. R.; FERRACANE, J. L. Pulse-delay curing: influence of initial irradiance and delay time on shrinkage stress and microhardness of restorative composites. Oper Dent. Indianapolis, v. 31, $\mathrm{n}$. 5, p. 610-5, Sep-Oct. 2006. https://doi.org/10.2341/05-118

PFEIFER, C. S; FERRACANE, J. L; SAKAGUCHI. R. L; BRAGA, R.R; Factors affecting photopolymerization stress in dental composites. J Dent Res. Manchester, v. 87, n. 11, p. 1043-7, Nov. 2008.

RODRIGUES, M. C. Influencia da variação de densidade de potencia na contração de polimerização f.e na pigmentação de resinas compostas fotossensíveis. 2011. 136 f Dissertação (Mestrado em Dentística) - Curso de Pós Graduação, Faculdade de Odontologia de Bauru, Bauru, 2011.

RUEGGEBERG, F. A.; CAUGHMAN, W. F.; CURTIS, J.W. JR.; Effect of light intensity and exposure duration on cure of resin composite. Oper Dent, Indianapolis, v. 19, n. 1, p. 26-32, Jan-Feb. 1994.

RUEGGEBERG, F. A.; CAUGHMAN, W. F.; CHAN, D. C. Novel approach to measure composite conversion kinetics during exposure with stepped or continuous light-curing. J Esthet Dent. New Jersey, v. 11, n. 4, p. 197-205, 1999.

SAKAGUCHI, R. L; VERSLUIS, A; DOUGLAS, W. H. Analysis of strain gage method for measurement of post-gel shrinkage in resin composites. Dent Mater., Manchester, v. 13, n. 4, p. 233-9, Jul. 1997.

https://doi.org/10.1016/S0109-5641(97)80034-6

SHARAFEDDIN, F., MORADIAN, M., MOTAMEDI, M. Evaluation of Shear Bond Strength of Methacrylateand Silorane-based Composite Resin Bonded to Resin-Modified Glass-ionomer Containing Micro- and Nanohydroxyapatite. J Dent (Shiraz). Shiraz, c. 17,n. 2, p. 142-8, 2016.

SOH, M. S; YAP, A. U. Influence of curing modes on crosslink density in polymer structures. J Dent. Manchester, v. 32, n. 4, p. 321-6, May.2004.

TANTBIROJN, D.; PFEIFER, C. S; BRAGA, R. R.; VERSLUIS, A. Do low-shrink composites reduce polymerization shrinkage effects? J Dent Res. Michigan, v. 90, n. 5, p. 596-601, May. 2011.

TAY, F. R.; PASHLEY, D. H.; YIU, C. K.; SANARES, A. M.; WEI, S. H. Factors contributing to the incompatibility between simplified-step adhesives and chemically-cured or dual-cured composites. Part I. Single-step self-etching adhesive. J Adhes Dent. New York, v. 5, n. 1, p. 27-40, Spring, 2003.a

TAY, F. R.; SUH, B. I.; PASHLEY, D. H.; PRATI, C.; CHUANG, S. F.; LI, F. Factors contributing to the incompatibility between simplified-step adhesives and self-cured or dual-cured composites. Part II. Singlebottle, total-etch adhesive. J Adhes Dent. New York, v. 5, n. 2, p. 91-105, Summer. 2003.b

VAN ENDE, A.; DE MUNCK, J.; MINE, A.; LAMBRECHTS, P.; VAN MEERBEEK, B. Does a lowshrinking composite induce less stress at the adhesive interface? Dent Mater. Manchester, v. 26, n. 3, p. 21522, Mar.2010. https://doi.org/10.1016/j.dental.2009.10.003

VAN MEERBEEK, B.; YOSHIHARA, K.; YOSHIDA, Y.; MINE, A.; DE MUNCK, J.; VAN LANDUYT, K.L. State of the art of self-etch adhesives. Dent Mater. Manchester, v.27,n.1, p.17-28, Jan. 2011. https://doi.org/10.1016/j.dental.2010.10.023

VERSLUIS, A.; TANTBIROJN. D.; DOUGLAS, W. H. Do dental composites always shrink toward the light? J Dent Res. Manchester. v. 77, n. 6, p. 1435-45, Jun.1998. 
WEINMANN, W.; THALACKER, C.; GUGGENBERGER, R. Siloranes in dental composites. Dent Mater. Manchester, v. 21, n. 1, p. 68-74, Jan. 2005. https://doi.org/10.1016/j.dental.2004.10.007

WEINMANN, W.; THALACKER, C.; GUGGENBERGER, R. Siloranes in dental composites. Dent Mater. Manchester, v. 21, n. 1, p. 68-74, Jan.2005. https://doi.org/10.1016/j.dental.2004.10.007

YAMAZAKI, P. C.; BEDRAN-RUSSO, A. K.; PEREIRA, P. N.; WSIFT, E. J. JR. Microleakage evaluation of a new low-shrinkage composite restorative material. Oper Dent. Indianapolis, v. 31, n. 6, p. 670-6, Nov-Dec. 2006. https://doi.org/10.2341/05-129 